\title{
Nursing in Collective Health: reinterpretation of objective reality by the praxis action
}

\author{
Enfermagem em Saúde Coletiva: reinterpretação da realidade objetiva por meio da ação praxiológica
} Enfermería en Salud Pública: reinterpretación de la realidad objetiva por medio de la acción praxiológica

\section{Emiko Yoshikawa Egry', Rosa Maria Godoy Serpa da Fonseca', Maria Amélia de Campos Oliveira', Maria Rita Bertolozzi'}

\author{
'Universidade de São Paulo, School of Nursing, Department of Nursing in Collective Health. São Paulo, Brazil.
}

\section{How to cite this article:}

Egry EY, Fonseca RMGS, Oliveira MAC, Bertolozzi MR. Nursing in Collective Health: reinterpretation of objective reality by the praxis action. Rev Bras Enferm [Internet]. 2018;71(Supl 1):710-5. [Issue Edition: Contributions and challenges of practices in collective health nursing] DOI: http://dx.doi.org/10.1590/0034-7167-2017-0677

\section{Submission: 09-21-2017 Approval: 12-13-2017}

\section{ABSTRACT}

Objective: To discuss the phase of reinterpretation of objective reality of the Theory of Praxis Intervention of Nursing in Collective Health (Tipesc), in search of the praxis that it promotes. Method: Analysis of interventions in projects that are based on Tipesc and its results, since the 1990s. Results: Developed and implemented projects show that praxis is the way to achieve the aimed changes. Conclusion: We concluded that Tipesc is currently the explanatory and interventional theory, since it is grounded on its theoretical bases, which arise from philosophical bases of dialectical and historical materialism.

Descriptors: Public Health; Community Nursing; Nursing Research; Research Methodology in Nursing; Nursing Theory.

\section{RESUMO}

Objetivo: Discutir a etapa da reinterpretação da realidade objetiva da Teoria de Intervenção Práxica da Enfermagem em Saúde Coletiva - Tipesc, em busca da práxis que ela fomenta. Método: Análise das intervenções realizadas em projetos que têm como base a Tipesc e seus resultados, desde a década de 1990. Resultados: Os projetos elaborados e implementados mostram que a práxis é o caminho para alcançar as transformações projetadas. Conclusão: Conclui-se pela atualidade da Tipesc como teoria explicativa e também interventiva, desde que enraizada em suas bases teóricas emanadas das bases filosóficas do materialismo histórico e dialético.

Descritores: Saúde Pública; Enfermagem Comunitária; Pesquisa em Enfermagem; Metodologia de Pesquisa em Enfermagem; Teoria de Enfermagem.

\section{RESUMEN}

Objetivo: discutir la etapa de la reinterpretación de la realidad objetiva de la Teoría de Intervención Práxica de la Enfermería en Salud Coletiva (Tipesc) en la búsqueda de la praxis que ella fomenta. Método: el análisis de las intervenciones realizados en los proyectos que tienen como base la Tipesc y sus resultados, desde la década de 1990. Resultados: los proyectos elaborados e implementados muestran que la praxis es el camino para alcanzar las transformaciones proyectadas. Conclusión: se concluye por la actualidad de la Tipesc como teoría explicativa y también intervencionista, desde que arraigada en sus bases teóricas emanadas de las bases filosóficas del materialismo histórico y dialéctico.

Descriptores: Salud Pública; Enfermería Comunitaria; Investigación en Enfermería; Metodología de Investigación en Enfermería; Teoría de Enfermería. 


\section{INTRODUCTION: BRIEFLY EXPLAINING THE THEORY OF PRAXIS INTERVENTION OF NURSING IN COLLEC- TIVE HEALTH AND ITS STEPS}

The Theory of Praxis Intervention of Nursing in Collective Health, published in a book by Editora Ícone, with the title Saúde Coletiva: construindo um novo método em Enfermagem (Collective Health: creating a new method in Nursing)(1), arose, as an idea, many years before.

To understand such fact, we must consider that the end of the 1970s and the early 1980s were marked by major structural changes in the Brazilian society, capitalist and peripheral, under the military dictatorship, in which freedom of expression was restrained. At the same time, there were movements against the regime, within the dialectics between the instituted and the instituing, characterizing exception times. If there were many structural changes, there were also many changes in nursing education, sometimes reiterating divergences, sometimes reinforcing more and more the conservative vision.

In this reflection, we focus on what occurred in nursing education in public health, more specifically in the subject taught by the School of Nursing of University of São Paulo, alias Preventive and Community Nursing ${ }^{(2)}$. Alias because the content was the same of the subjects Public Health Nursing I, II, and III, in force since the 1960s.

This name arose in the restructure of University of São Paulo, in which one of the proposed changes would be to unite, into a single unit - the School of Public Health -, all subjects focusing on or referred to as public health, for the specialization courses.

Leaders of preventive and community health care at the time did not explain the difference between Preventive and Community Nursing and Public Health Nursing. They just covered it to preserve, within the curriculum of the undergraduate program - Bachelor's Degree in Nursing -, the syllabus considered essential for all seniors, regardless of whether they aimed to work in the fields of public health (primary health care units, health centers, outpatient clinics, sanitary districts, hospitals for contagious diseases) or in those of individual health care such as in hospital nursing.

At the time, the effervescence of social movements eventually reached the understanding of what is nursing. There was the outbreak of a movement in favor of nursing as a social and work practice, and no more - as schools of nursing used to teach - as a vocation or charity exercise. This was a very interesting nationwide movement, which changed for good the course of nursing practice and education in the country.

Thinking about the origin of Tipesc, it is noteworthy that the participation of professors in the field of Preventive and Community Nursing, in meetings with teachers, workers and students from the University of São Paulo, in addition to the social movements increasingly part of the university life, made professors of the School of Nursing to step outside the comfort zone provided by the profession vocational idealist understanding and to face lucid criticism and analyses of social scientists and philosophers, in order to discuss the work at the University. Therefore, readings of other worldviews were recommended to explain the Marxist labor theory. Few, but important subjects, have been offered in the field of health, and we must mention the one taught by professor Maria Cecília Donângelo, sociologist, who taught edifying classes on the praxis philosophy, with contents that would enrich a superlative group doctors, nurses, social workers, nutritionists, dentists, among others, in search of more effective social changes.

We may say that confronting nursing theories, idealists in their worldview, with Marxian theories was shocking. In the practice of Preventive and Community Nursing education, the shock was replaced by the inability of the professor to teach nursing health care to the family of the functionalist and Cartesian point of view, as much as to teach classic epidemiology to understand the collective side of public health.

Thus, it was no longer possible to teach nursing health care with conceptual milestones adopted at that time, even with the aid of Rogerian pedagogy. Therefore, it was necessary to create the first systematic work of nursing health care based on dialectical and historical materialism, contained in an article by Queiroz \& Egry (1998) ${ }^{(3)}$.

In this study, the authors address the Marxian thinking from the books of Marx and critical epidemiology by Breilh \& Granda $(1986)^{(4)}$, which became the first essay that would later result in Tipesc.

Soon after, Egry (1994) wrote and defended his habilitation thesis ${ }^{(5)}$, entitled Elementos teórico-metodológicos para a intervenção práxica da enfermagem em saúde coletiva (Theoreticalmethodological elements for the praxis intervention of nursing in Collective Health). Between the article and the thesis, the Department of Nursing in Collective Health was founded, in February 1987, based on dialectical and historical materialism, promising to give voice to the praxis episteme. In 1996, the thesis resulted in the book Saúde Coletiva: construindo um novo método em enfermagem (Collective Health: creating a new method in nursing), which addressed the current knowledge of the subject ${ }^{(1)}$.

Tipesc was created to understand the contradictions of the objective reality of nursing in Collective Health, this considered as a theoretical and practical field. It is a theory of nursing, based on the historical and dialectical materialist worldview, which seeks the nursing intervention by a dynamic, dialectical, and participatory methodology. Its philosophical bases are historicity and dynamism. Historicity is related to the historical materialism and characterizes the constant mobility of history, the continuous "come-into-being" of social transformations. Reality is perceived as having the quality of being temporary, unstable, labile, imperfect, and dubious Rooted in historicity, as mentioned by Marx, is the vision of the progress of history that seeks the ultimate cause and the great driving force of all the important events, in the economic development of the society, in the transformation of modes of production and of exchange, in the consequent division of society into distinct classes and the fight between them (Egry, 1996) ${ }^{(6)}$.

The materialistic dialectical and historical method is characterized by the

movement of thought through the historical materiality of man's life in society, that is, it is to discover (by the movement of thought) the fundamental laws that define the organizational 
form of man during the history of mankind. According to the principle of contradiction, part of this logic, when thinking about reality you can accept contradiction, walk by it, and grasp what it is essential in it. In this logical path, moving the thought means to reflect on the reality from the empirical (the presented reality, the apparent real, the object as it is presented at first sight) and, through abstractions (elaborations of thought, reflection, theory), to reach the concrete: more elaborate understanding of what is essential in the object, object which is a synthesis of multiple determinations, a thoughtful concrete. Thus, the difference between empirical (apparent real) and concrete (thoughtful real) are the abstractions (reflections) of thought that make the reality observed more complete ${ }^{(7)}$.

Egry, Fonseca, Apostólico et al. (2017) ${ }^{(6)}$ thus summarize the central issues of Tipesc:

\begin{abstract}
Philosophical bases of Tipesc, therefore, are in accordance with the understanding of historical materialism and dialectical materialism. Theoretical Bases of Tipesc derive from such worldview. They are conceptual categories and dimensional categories. The concepts that pervade our works in health are: society, man, health-disease process, Collective Health, health care, nursing, work, need, vulnerability, and education (Egry, 2010). Dimensional categories are shaped by the set of concepts considered in the development process of Tipesc, i.e., in operation. For being dimensional, they are not isolated from each other, there is a continuous permeability between the categories. Three dimensional categories are key to Tipesc: totality, praxis, and interdependence on the structural, particular, and singular (Egry, 1996). Totality is understood as the comprehension of the part-to-whole relationship: it allows the understanding of reality in its intrinsic laws and the disclosure of its necessary internal connections; it demonstrates a process of aggregation from the relations of production and its contradictions. Praxis refers to the dialectical theory-practice unit. For Konder (1992:102), praxis, in the Marxian sense, is the "concrete activity with which subjects place themselves in the world, modifying the objective reality, and becoming themselves in order to change it". It is the activity that, to be more aware of it, needs reflection, selfquestioning, theory; and it is the theory that refers to action, that faces the challenge of verifying agreements and misunderstandings, comparing them with practice. The interrelation between the structural, particular, and singular dimensional category allows, simultaneously, to enlighten the different parts of the phenomenon and to expose the dialectics between these parts altogether. The structural refers to the greatest totality of the phenomenon; the particular is the mediation between the structural and the singular; and the singular is the minor totality (Egry, 2010). Tipesc is part of the list of theoretical-methodological instruments that may enable nurses to exercise a criticism concerned about the change of the current mode of organization of society, of policies for preventing violence, and practices for the intervention in the phenomenon ${ }^{(8)}$.
\end{abstract}

Under this theoretical and philosophical basis, Tipesc works in five steps ${ }^{(1)}$ :

1. Objective reality perception - to understand the phenomenon and to describe its situation (like a picture of the moment) and historicity (just like a movie in which you show the past of this phenomenon, its origin and main transformations, linked to the transformation processes of society in which the phenomenon or objective reality are inserted, in its production mode and social reproduction) in three dimensions of reality: structural, particular, and singular;

2. Interpretation of the objective reality - more than approaching explanatory theories of the phenomena occurrence, this step enables understanding dialectical contradictions, demonstrating the unity and struggle of opposites within the phenomenon and its interface with the adjacent parts of the totality of which the studied phenomenon is part. To specify the contradictions in terms of polarity, also in the three dimensions of the objective reality, enlightens what is possible to change and, therefore, supports interventions planned in reality. In addition to exposing the polarities dialectically contradictory, previous transformations that the phenomenon has suffered should also be thoroughly analyzed, either considering their own inherent quality, or the immediately preceding radical transformation - the so-called origin or birth of the phenomenon, with its essential characteristics. In other words, it is to expose the dialectical paths taken by the phenomenon within the fundamental laws of Marxian dialectics;

3. Proposal of intervention in the objective reality - in this step, we plan an intervention in the objective reality, aiming at overcoming the phenomenon from what has greater vulnerability to transformation. Vulnerability, in this case, indicates not only the fragility of the phenomenon to remain as it is, but also the strength of knowledge (ethical-professional know how to know, know how to do, and know how to be) within the reach of those who make the intervention. We highlight the importance of participation as a premise for the proposed intervention, since the unilateral preparation of the movement do not often results in the aimed potential for change. For instance, we could mention interventions unilaterally proposed by health workers regarding qualification in terms of the development of health potential of the subjects who inhabit the territory. If made with the participation of the subjects who compose the territory, it would result in an intervention with a much greater possibility of transformation, considering that all the participants would be actors in the process, therefore, potentially, everyone would be responsible for it;

4. Intervention in the objective reality - processes initiated in a critical, reflective, and, at the same time, educational way, for the acquisition of competencies in terms of the changes planned in the previous phase. We emphasize the responsibility shared between health workers, social groups of the territories, local and state administrators in general, in addition to the involvement of actors from other social organizations present or required in the territory; 
5. Reinterpretation of the objective reality - this step finishes the combination of the product evaluation (undergone changes, evidence that certain interventions have resulted in improvements reaching the collective) and the process evaluation (which data subsequently collected present more chance of transforming the reality, which relations between the subjects could give greater strength to the transformations, or, on the contrary, hindered the agreements initially made, difficulties in assuming shared responsibility, and the solutions adopted; the impact on other health-related areas such as education). For instance: Was there a movement to include in the Plano Municipal de Saúde (Municipal Health Plan - PMS) the provision of adult education at times and locations that allow their attendance? Were the health needs and vulnerabilities of this social group informed in the PMS? Did evaluations from Relatórios Municipais de Gestão (Municipal Management Reports) adopt criteria related to the critical reading of the epidemiology of the territories?

\section{EMPHASIS OF REINTERPRETATION OF THE OBJEC- TIVE REALITY: CRITICISM TO ENHANCE THE CHANGE POTENTIAL}

Two decades after the publication of the edition of the book Saúde Coletiva: construindo um novo método em enfermagem (Collective Health: creating a new method in nursing) ${ }^{(1)}$, the phase of reinterpretation of the objective reality is one of those that should be the most revised, considering the amount of experiences of Tipesc implementation over the years with the students and alumni of the subjects Public Health Nursing I and II, of the Graduate Program in Nursing of the School of Nursing, University of São Paulo.

Since 1990, these two subjects are being taught without interruption by the authors of this reflection. We can say that Tipesc has been consolidated within these subjects because of intense discussion about the dialectical and historical materialism and of its implementation in the field of nursing. This alliance of the Marxian philosophical basis with the theories and practices of the so-called Nursing in Public Health has created the conditions for the dialectical overcoming that resulted in the creation of the epistemological field of Nursing in Collective Health, founded and based in the Department of Nursing in Collective Health at the School of Nursing of the University of São Paulo (EEUSP).

Tipesc has established the primary content of the two Master's compulsory subjects of the area focused on Public Health of the Graduate Program in Nursing of EEUSP. Its episteme has also been debated in university extension courses taught throughout the country. It was also a reading reference of a national project carried out by Associação Brasileira de Enfermagem (Brazilian Association of Nursing - ABEn), coordinated by the International Council of Nurses, Project of International Classification of Nursing Practices in Public Health - CIPESC, nowadays a trademark of $\mathrm{ABEn}^{(9)}$. Over two decades, these experiences allowed submitting theoretical, methodological, instrumental, political, and pedagogical lines of Tipesc to the practice test.
We may say that there are several studies conducted by former master's, PhD, and postdoctoral students, together with the professors of the aforementioned subjects, who revisited and continue revisiting their practices or objective realities to perceive, interpret, and project the required transformations. Changes that occurred in the graduate program itself urged the admission of professionals from other health areas other than nursing. The participation of psychologists, occupational therapists, social workers, nutritionists, physical therapists, and doctors, as well as nurses, have greatly enriched the implementation potential of Tipesc, which, as expected, turned out to be a methodology for intervention in objective realities, based on theoretical-methodological milestones reconsidered in light of dialectical and historical materialism.

It is noteworthy that none of the contradictions previously mentioned in the book chapter that discussed reinterpretation was essentially overcame, that is, if there were changes, they were more quantitative than qualitative overcomings.

However, the intensive implementation of Tipesc, to the most different situations and scenarios, evidenced other facets and possibilities, as follows:

a) Tipesc implementation studies highlight privileged phenomena, such as the organization of the work of agents, their processes and products, in addition to their ideological knowledge, more than instrumental knowledge. The study of phenomena in the objective reality dimensions has shown contradictions found in the structural, particular, and singular dimensions, enabling researchers to understand the dialectical totality of specific work processes involved. Even for studies that promptly address the necessary implementation of an instrument as a problem or theme, such as the nursing consultation, or questioning the meaning and the real health care practices, when implementing Tipesc it was possible to understand the dialectics between form and content, historicity and situation, necessity and causality, and, especially, appearance and essence;

b) Over time, objective reality proved to be powerful to create information-gathering and organization instruments of Tipesc considering its methodology (the socalled Metisc -Methodology of Intervention in Collective Health). However, these instruments were created with reluctance, because they could restrict the creative processes for elaborating more appropriate tools or those closer to reality, since no instrument can truly grasp the variations arising from the diversity of health care practices carried out in such immense country. We have used these instruments in graduate programs classes because, although considering the limitations previously described, they illustrate the instrumental possibility of Tipesc, although subject to all necessary modifications. Indeed, instruments were designed mainly considering the health care reality of the city of São Paulo and its possibilities, except for the redesigned social instrument produced for the scenario of Curitiba, Paraná ${ }^{(10)}$. 
The instruments have already been successfully applied to the reality of several cities. Surprisingly (for us), their implementation in work environments other than that of nurses was very successful. Heated discussions about the perceived contradictions and overcoming projects have organized a trial of interdisciplinarity in the proposed interventions;

c) A few years ago, Tipesc had the privilege of being analyzed by professors of graduate students of the Federal University of Ceará. The debate resulted in a book chapter ${ }^{(11)}$ in which they tried to analyze it thoroughly, placing it in the set of critical theory as theoretical basis and not directly of the source of the dialectical and historical materialism. According to these authors,

Tipesc is a theory of multidisciplinary bases. It considers conceptual and explanatory elements of sociology, anthropology, epistemology, economics, ecology, politics, and epidemiology. It covers different fields such as planning, management, and health care. This theory dimension enriches its analytical and explanatory capacity ${ }^{(11)}$.

Although this might be true, for us, authors of this essay, pure and simple affiliation of Tipesc to the critical theory is more a limiting vector than one which is opened to possibilities. Having as basis the dialectical and historical materialism (DHM) as a philosophical milestone, attributing a meaning to its application to health practices, such as it has been built in this country in the last 100 years, we sought to find the contradictions of the theoretical milestone itself and meanings attributed to the DHM by the dialectical conception of health-disease. It is just the beginning, not the end. Hence, it is not a dogmatic adoption of a theoretical model of the 19th century, as the authors of the book suggest. Still, the alert is important to all those who seek the implementation of Tipesc. However, we recommend the full reading of the book, not only of the mentioned chapter. The debate follows, for sure, and hopefully the winner will be the improved health-disease profile of Brazilian populations, or the improvement in technical, ethical, and political qualifications of health and education professionals;

d) The hierarchy of interventions is due to ethical-political competencies. Health actions have funding or the cost of health care as counterpart. It means there are no resources available to meet everybody needs, in such a way that it must be decided which are the sectors receiving something, whatever the amount or size of the source available in health care. Ethical-political competencies, unlike what many people think, are not competencies to be developed by professionals only, but also by users-citizens or professionals-citizens, as part of the defense of the quality of life, and the field of health care is only one which assumes this responsibility. Therefore, the more competencies are developed, the greater the possibility to define the hierarchy of interventions, so that they are consistent, useful, and important to the collective formed by social groups distinguished among themselves and internally homogeneous. The ethicalpolitical competence of all formulators and implementors of health policies must consider expenditures on health care as an investment in the quality of life of the population of the territories. A study conducted by Maeda, Ciosak \& Egry $(2010)^{(12)}$ shows the ideological perspective of the ownership of the production costs of a health care, exemplified in prenatal care.

\section{FINAL CONSIDERATIONS}

By reinterpreting the paths taken, we note that the most enduring and committed projects to the transformation of reality were the ones which were able to combine ethics with the joint creation of changes in the definition of overcoming horizons. We must resist the temptation to conceive and apply projects easily implemented, when only an authority or a professional assumes the transformations. This is hard, particularly at this time when quantity by itself says it all in the evaluations in the fields of health care and education, and have consequences in financing of development agencies.

Resisting the siren song is to provide quality interventions, not just by following the principle of shared responsibility, but also by developing the critical conscience of everyone involved in the processes. In these cases, continuity possibilities are better, that is, sustainability is given by the conscious participation of the subjects of transformation processes, changes that are real, deep, intelligent, creative, and humane.

\section{ACKNOWLEDGEMENTS}

We thank the National Council of Scientific and Technological Development (CNPq) for granting Research Productivity Scholarships; the Department of Nursing in Collective Health of the School of Nursing, University of São Paulo, for providing conditions for the development of this study.

\section{REFERENCES}

1. Egry EY. Saúde Coletiva: construindo um novo método em enfermagem. São Paulo: Ícone; 1996.

2. Fonseca RMGS, Bertolozzi MR, Chiesa AM, Greco RM, Egry EY. Desenvolvendo um processo ensino-aprendizagem: pré-requisitos e métodos de ensino na disciplina de enfermagem preventiva e da comunidade em um curso de graduação em enfermagem. Rev Esc Enferm USP. 1992;26:419-26.

3. Queiroz VM, Egry EY. Bases metodológicas para a assistência de enfermagem fundamentadas no materialismo histórico e dialético. 
Rev Bras Enferm. 1988;41(1):26-33.

4. Breilh J, Granda E. Investigação da saúde na sociedade: guia pedagógico sobre um novo enfoque do método epidemiológico. São Paulo: Instituto de Saúde/ABRASCO; 1986.

5. Egry EY. Elementos teórico-metodológicos para a intervenção práxica da enfermagem em saúde coletiva [Tese]. Escola de Enfermagem. Universidade de São Paulo. 1994

6. Egry EY, Fonseca RMGS, Apostólico MR, Cubas MR, Chaves MMN, Rehem T. O coletivo como objeto do cuidado de enfermagem: uma abordagem qualitativa. In: Costa AP, Sánchez-Gómez MC, Cilleros MVM. A prática na investigação qualitativa: exemplos de estudos. Aveiro, Portugal: Ludomedia; 2017. p.111-45.

7. Pires MFC. O materialismo histórico-dialético e a educação. Interface: Comunic Saúde Educ. 1997;1(1):83-92

8. Egry EY, Cubas MR, Nichiata LYI. Instrumentos de leitura e necessidades de saúde: geoprocessamento, inquérito populacional e CIPESC ${ }^{\circledR}$. In: Soares CB, Campos CS (Org.). Fundamentos de Saúde Coletiva e o Cuidado de Enfermagem. Barueri: Manole; v.1, 2013. p. 369-87

9. Egry EY, Cubas MR, Antunes MJM, Lopes MGD, Nóbrega MM, Martins SK, Albuquerque LM, Fonseca RMGS. CIPESC no Brasil. In: Associação Brasileira de Enfermagem (Org.). Associação Brasileira de Enfermagem 1926-1976: documentário. 3. ed., Brasília: ABEn; 2013. p.171-235.

10. Cubas MR, Egry EY. Innovator practices in collective health: re-reading tool of the health disease process. Rev Esc Enferm USP [Internet]. 2007[cited 2017 Aug 23];41(spe):787-92. Available from: http://www.scielo.br/pdf/reeusp/v41nspe/v41nspea07.pdf

11. Silva MJ, Almeida MI, Moreira RVO. A teoria crítica e a teoria da enfermagem. In: Barreto JAM, Moreira RVO, (Orgs.). A decisão de Saturno: filosofia, teorias de enfermagem e cuidado humano. Fortaleza: UFC; 2000. p.147-78.

12. Maeda ST, Ciosak SI, Egry EY. [Methodology for appropriation of production costs in primary prenatal care]. Cienc Saúde Colet [Internet]. 2010 [cited 2017 Aug 23];15(sup-1):987-96. Available from: http://www.scielo.br/pdf/csc/v15s1/005.pdf 